\title{
Role of Transiently Altered Sarcolemmal Membrane Permeability and Basic Fibroblast Growth Factor Release in the Hypertrophic Response of Adult Rat Ventricular Myocytes to Increased Mechanical Activity In Vitro
}

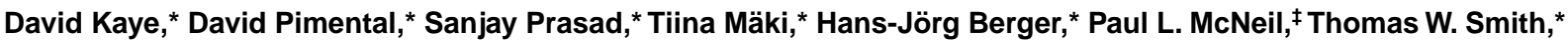 \\ and Ralph A. Kelly \\ *Cardiovascular Division, Department of Medicine, Brigham and Women’s Hospital, Boston, Massachusetts, and the ${ }^{\ddagger}$ Department of Cell \\ Biology and Anatomy, Medical College of Georgia, Augusta, Georgia
}

\begin{abstract}
One of the trophic factors that has been implicated in initiating or facilitating growth in response to increased mechanical stress in several tissues and cell types is basic fibroblast growth factor (bFGF; FGF-2). Although mammalian cardiac muscle cells express bFGF, it is not known whether it plays a role in mediating cardiac adaptation to increased load, nor how release of the cytosolic $18-\mathrm{kD}$ isoform of bFGF would be regulated in response to increased mechanical stress. To test the hypothesis that increased mechanical activity induces transient alterations in sarcolemmal permeability that allow cytosolic bFGF to be released and subsequently to act as an autocrine and paracrine growth stimulus, we examined primary isolates of adult rat ventricular myocytes maintained in serum-free, defined medium that were continually paced at $3 \mathrm{~Hz}$ for up to $5 \mathrm{~d}$. Paced myocytes, but not nonpaced control cells, exhibited a "hypertrophic" response, which was characterized by increases in the rate of phenylalanine incorporation, total cellular protein content, and cell size. These changes could be mimicked in control cells by exogenous recombinant bFGF and could be blocked in continually paced cells by a specific neutralizing anti-bFGF antibody. In addition, medium conditioned by continually paced myocytes contained significantly more bFGF measured by ELISA and more mitogenic activity for $3 \mathrm{~T} 3$ cells, activity that could be reduced by a neutralizing anti-bFGF antibody. The hypothesis that transient membrane disruptions sufficient to allow release of cytosolic bFGF occur in paced myocytes was examined by monitoring the rate of uptake into myocytes from the medium of $10-\mathrm{kD}$ dextran linked to fluorescein. Paced myocytes exhibited a significantly higher rate of fluoresceinlabeled dextran uptake. These data are consistent with the hypothesis that nonlethal, transient alterations in sarcolemmal membrane permeability with release of cytosolic bFGF is one mechanism by which increased mechanical activity could lead to a hypertrophic response in cardiac myocytes.
\end{abstract}

Address correspondence to Ralph A. Kelly, M.D., Cardiovascular Division, Brigham and Women's Hospital, 75 Francis Street, Boston, MA 02115. Phone: 617-732-7503; FAX: 617-732-5132; E-mail: rakelly@bics.bwh.harvard.edu

Received for publication 5 April 1995 and accepted in revised form 29 September 1995.

J. Clin. Invest.

(c) The American Society for Clinical Investigation, Inc.

0021-9738/96/01/281/11 \$2.00

Volume 97, Number 2, January 1996, 281-291
(J. Clin. Invest. 1996. 97:281-291.) Key words: angiogenesis - fluorescence-activated cell sorting $\bullet$ 2,3-butanedione monoxime

\section{Introduction}

The growth response of postnatal mammalian ventricular myocytes to increased mechanical activity or load is limited to cellular hypertrophy, as these cells have lost the capacity to enter the cell cycle and undergo cytokinesis. This response is associated with an increase in protein synthesis and cell size. In the intact animal and in isolated papillary muscle preparations, physiologic alterations in ventricular loading conditions show a clear relationship with the degree of hypertrophy elicited (1). There is also a characteristic reexpression in ventricular muscle of a number of genes associated with cardiac development, such as atrial natriuretic peptide and, in rodents, an increase in the ratio of $\beta$ myosin heavy chain to $\alpha$ myosin heavy chain isoforms $(2,3)$. The reexpression of these genes may be due to a genetically limited range of responses available to adult ventricular myocytes in the process of adapting to changes in mechanical load or activity. It also may reflect in part the activity of one or more specific trophic factors that initiate and/or facilitate the growth response (3).

The nature of the initial signal(s) that transduce an increase in myocyte mechanical activity or load, and that subsequently initiate the cellular processes that regulate the transition to hypertrophy, remain unclear. Increased sympathetic nervous system activity or thyroid hormone levels may initiate myocyte growth independent of changes in mechanical activity. $\alpha$-Adrenergic receptor activation, for example, will initiate a cascade of signaling events, mediated initially by phospholipase $\mathrm{C}$, that results in an increase in mitogen-activated protein kinase $(\mathrm{MAPK})^{1}$ activation, increased synthesis of contractile proteins, and a transition to a hypertrophic phenotype (4-9). A number of other autocrine- and paracrine-acting peptide trophic factors, which trigger either GTP-binding protein or tyrosine kinase-linked receptor signaling mechanisms, have also been shown to activate MAPKs and have been implicated in the growth response of cardiac muscle $(10,11)$. Several mechanisms have been proposed that could transduce a change in mechanical stress on the cell into a growth signal that could be

1. Abbreviations used in this paper: aFGF, acidic fibroblast growth factor; BDM, 2,3-butanedione monoxime; bFGF, basic fibroblast growth factor; DMEM, Dulbecco's minimum essential medium; KHB, Krebs-Henseleit bicarbonate; MAPK, mitogen-activated protein kinase; rhbFGF, recombinant human bFGF. 
mediated in part by increased expression, activation, and release of one or more of these peptide trophic factors. These include participation of stretch-activated ion channels (12), alterations in the binding of integrin receptors to surrounding extracellular matrix proteins (13), activation of plasmalemmal $\mathrm{Ca}^{2+}$ channels that initiate both protein kinase $\mathrm{C}$ and cAMP-dependent growth stimuli $(14,15)$, and an increase in internal cytoskeletal tension that may be transferred directly to the nucleus: for example, the involvement of $c i s$-acting shear stress-responsive promoter elements in endothelial cells $(16,17)$.

While evidence exists for each of these mechanisms in several cell types, none has been shown conclusively to play a role in mediating the hypertrophic response to increased mechanical stress in cardiac myocytes. It is possible that increased mechanical stress on other constituent cells in cardiac muscle, such as fibroblasts or endothelial cells in the microvasculature, for example, could result in the release of paracrine-acting trophic factors. However, this does not preclude the possibility that cardiac myocytes also exhibit one or more mechanisms for directly transducing changes in mechanical load or activity into an autocrine growth signal.

Both basic fibroblast growth factor (bFGF; FGF-2) and acidic fibroblast growth factor (aFGF; FGF-1) have been identified in terminally differentiated, postmitotic adult cardiac muscle cells, with subcellular localization to the cytoplasm, nucleus, and gap junctions at intercalated disks (18-22). FGFs released from these cells could act in an autocrine manner or on neighboring myocytes or other cell types in ventricular muscle. Both heparin-binding growth factors have been shown to play an important role during cardiac ontogeny and have also been demonstrated to elicit a transition to a hypertrophic phenotype in neonatal ventricular myocytes (23-26). However, none of the aFGF and bFGF isoforms that have been described to date have $\mathrm{NH}_{2}$-terminal signal sequences that facilitate protein trafficking through the endoplasmic reticulum and Golgi apparatus to classic secretory pathways (27).

Therefore, the mechanism(s) that initiate their release remain unclear. In this manuscript, we address the hypothesis that transient membrane disruptions or changes in sarcolemmal permeability, a process that we have termed "membrane wounding," may accompany increased myocyte mechanical activity and facilitate the release of bFGF (28-30). To test this hypothesis, we used an in vitro model in which freshly isolated cardiac myocytes from adult rat ventricular muscle were induced to beat continually by uniform electric field pacing for a period of several days in a defined medium that contained no growth-initiating trophic factors. Compared with control, nonbeating, "quiescent" myocyte cultures, paced myocytes released significantly more bFGF into the surrounding medium and exhibited an increase in cellular protein content and cell size, indicative of a transition to a hypertrophic phenotype. A role for bFGF in this process was assessed using a specific neutralizing anti-bFGF antibody. The neutralizing antibody blocked the increase in paced myocyte protein content as well as a portion of the $3 \mathrm{~T} 3$ cell mitogenic activity released into defined medium conditioned by paced, but not by quiescent, adult ventricular myocytes. Finally, the potential role of altered permeability properties induced by continual mechanical contraction during pacing was assessed by tracking the rate of uptake into paced and quiescent cells of a fluorescein-labeled dextran approximately equivalent in size to the $18-\mathrm{kD}$ cytosolic isoform of bFGF.

\section{Methods}

\section{Isolation and culture of adult rat ventricular myocytes}

Calcium-tolerant cardiac myocytes were isolated from adult rat ventricles as previously described (31). In brief, hearts were rapidly excised from male Sprague-Dawley rats (175-250 g; Charles River Laboratories, Wilmington, MA) under ether anesthesia, and then perfused via the ascending aorta with Krebs-Henseleit bicarbonate (KHB) buffer $\left(110 \mathrm{mM} \mathrm{NaCl}, 4.0 \mathrm{mM} \mathrm{KCl}, 1.0 \mathrm{mM} \mathrm{CaCl}_{2}, 0.9 \mathrm{mM}\right.$ $\mathrm{MgSO}_{4}, 0.9 \mathrm{mM} \mathrm{K}_{2} \mathrm{HPO}_{4}, 19.2 \mathrm{mM} \mathrm{NaHCO}$, and $11 \mathrm{mM}$ glucose) that had been equilibrated to $\mathrm{pH} 7.4$ with $5 \% \mathrm{CO}_{2}-95 \% \mathrm{O}_{2}$. After 5 min of perfusion with $\mathrm{KHB}$ buffer, a nominally $\mathrm{Ca}^{2+}$-free $\mathrm{KHB}$ buffer was substituted until beating ceased. At this point, enzymatic digestion was initiated by perfusing the hearts with nominally $\mathrm{Ca}^{2+}$. free KHB containing $0.05 \%$ collagenase (Worthington Biochem Corp., Freehold, NJ) and $0.03 \%$ hyaluronidase (Sigma Chemical Co., St. Louis, MO) until the hearts became flaccid. The atria, great vessels, and valvular apparatus were excised, and the remaining ventricular tissue was minced and further digested in collagenase/hyaluronidase-containing buffer with additional trypsin $(0.02 \mathrm{mg} / \mathrm{ml}$; Sigma Chemical Co.) and deoxyribonuclease $(0.02 \mathrm{mg} / \mathrm{ml}$; Sigma Chemical Co.). After digestion of the ventricular tissue, the cardiac myocytes were segregated from the nonmyocyte cellular fraction by a series of differential sedimentation gradient steps through a BSA cushion, as previously described (31). The final cell suspension, which typically consisted of at least $95 \%$ myocytes, was then resuspended in medium 199 containing Earle's salts (Sigma Chemical Co.) with 25 mM Hepes and $\mathrm{NaHCO}_{3}$, supplemented with albumin $(2 \mathrm{mg} / \mathrm{ml})$, L-carnitine (2 $\mathrm{mM})$, creatine $(5 \mathrm{mM})$, taurine $(5 \mathrm{mM})$, L-glutamine $(1.3 \mathrm{mM})$, insulin $(0.1 \mu \mathrm{M})$, triiodothyronine $(0.1 \mathrm{nM})$, pyruvate $(2.5 \mathrm{mM})$, penicillin $(100 \mathrm{U} / \mathrm{ml})$, streptomycin $(100 \mu \mathrm{g} / \mathrm{ml})$, and gentamicin $(100 \mu \mathrm{g} / \mathrm{ml})$. This medium, referred to as ACCITT in Ellingsen et al. (32), is termed "defined medium" throughout this report. These primary myocyte isolates were maintained at $37^{\circ} \mathrm{C}$ in $5 \% \mathrm{CO}_{2}$. The medium was changed $1 \mathrm{~h}$ after plating to remove loosely attached cells, with subsequent changes at 24-h intervals.

\section{Continual uniform electric field stimulation of adult ventricular myocytes}

Continual uniform electrical field stimulation was performed according to methods previously established in this laboratory (31). In brief, $3-4 \times 10^{6}$ cells were plated on laminin-coated $(5 \mu \mathrm{g} / \mathrm{ml}) 175-\mathrm{cm}^{2}$ tissue culture flasks (Ezin Flasks; Nunc, Roskilde, Denmark), to which a custom-designed electrostimulation device using parallel graphite electrodes was attached. Electrical stimulation was initiated $6 \mathrm{~h}$ after plating and could be continued for up to $1 \mathrm{wk}$, with medium changes every $24 \mathrm{~h}$. In all experiments, the stimulation frequency was $3 \mathrm{~Hz}$, and the stimulus voltage was adjusted according to the pacing capture rate (which was typically $>70 \%$ at $0.5 \mathrm{~V} / \mathrm{cm}^{2}$ ). Electrical impulses were triggered by computer, and the polarity of each successive stimulus was reversed as previously described (31).

\section{Assessment of myocyte phenotypic response to pacing and to recombinant $b F G F$}

A comprehensive assessment of the cellular response to electrical stimulation, and to exogenously added recombinant human bFGF (rhbFGF; R \& D Systems, Minneapolis, MN), was undertaken.

Morphometric analysis. Isolated myocytes were plated on laminin-coated glass cover slips, which were then placed in stimulation flasks for continual uniform electric field pacing as described above. Control myocytes and those exposed to exogenous rhbFGF were handled in a similar manner, except that pacing was not initiated. At appropriate time points, stimulation was terminated and the cover slips were transferred for phase-contrast and digital imaging microscopy. For determination of two-dimensional cell area, an observer blinded to the experimental group of cells being imaged identified the cell border, and the imaging software calculated the total cellular area (Inovision Corp., Durham, NC). 
Measurement of $\left[{ }^{3} \mathrm{H}\right]$ phenylalanine incorporation rate. One index of the rate of protein synthesis in isolated ventricular myocytes was assessed by determining the rate of incorporation of $\left[{ }^{3} \mathrm{H}\right]$ phenylalanine into total cellular protein. Myocytes were radiolabeled with 2.5 $\mu \mathrm{Ci} / \mathrm{ml}\left[{ }^{3} \mathrm{H}\right]$ phenylalanine (New England Nuclear, Bedford, MA) for $6 \mathrm{~h}$. Cells were then washed with a buffered phosphate solution and harvested in a lysis buffer containing $20 \mathrm{mM}$ Tris- $\mathrm{HCl}, 0.5 \mathrm{mM}$ EDTA, $0.3 \mathrm{mM}$ EGTA, $1 \mathrm{mM}$ dithiothreitol (DTT), and $1 \mu \mathrm{M}$ leupeptin (all from Sigma Chemical Co.). The specific activity of $\left[{ }^{3} \mathrm{H}\right]$ phenylalanine was determined by scintillation counting of samples precipitated with $10 \%$ TCA (followed by resuspension in $50 \mathrm{mM}$ Tris buffer), and are expressed in dpm/ $\mu \mathrm{g}$ DNA. Cellular DNA content was determined by a fluorometric assay (33). After cell lysis, samples were resuspended in a buffer composed of $100 \mathrm{mM}$ Tris, 10 $\mathrm{mM}$ EDTA, $1 \mathrm{M} \mathrm{NaCl}$, and $10 \mu \mathrm{g}$ of the fluorochrome H33258 (Calbiochem Corp., Richmond, CA).

Changes in total cellular protein. After precipitation of myocyte lysates with $10 \%$ TCA and resuspension in $50 \mathrm{mM}$ Tris buffer, aliquots were removed for determination of cellular protein and DNA content. Total cellular protein was determined by the Bradford method using Coomassie Blue (BioRad Laboratories, Melville, NY). Cellular protein content was normalized to DNA content as noted above.

\section{Effect of pacing on bFGF release by ventricular myocytes}

The possible release of bFGF from electrically stimulated ventricular myocytes and subsequent autocrine actions of this cytokine growth factor were assessed in three complementary ways. First, the presence and quantification of the release of trophic substances into the defined medium by quiescent or paced ventricular myocytes was performed using a $3 \mathrm{~T} 3$ cell bioassay. $15 \mathrm{~min}$ before the collection of myocyte-conditioned medium, heparin sulfate $(10 \mu \mathrm{g} / \mathrm{ml}$; Sigma Chemical Co.) was added to the medium to facilitate the collection of heparinbinding peptide growth factors. The medium was then collected and stored at $-70^{\circ} \mathrm{C}$ for subsequent assay. The myocytes were suspended as described above and an aliquot was used for assay of DNA content. The presence of trophic activity in the medium was quantified by exposing Swiss 3T3 fibroblasts (American Type Culture Collection, Rockville, MD) plated in $96-$ well cluster plates to a $200-\mu \mathrm{L}$ aliquot of myocyte-conditioned medium in the presence of $0.5 \mu \mathrm{Ci} / \mathrm{ml}$ $\left[{ }^{3} \mathrm{H}\right]$ thymidine and $0.5 \%$ FCS in Dulbecco's minimal essential medium (DMEM; GIBCO BRL, Gaithersburg, MD). After $24 \mathrm{~h}$ of incubation, the 3T3 cells were washed three times with DMEM and lysed with $2 \%$ Triton $\mathrm{X}-100$. The specific activity of thymidine was determined by liquid scintillation spectroscopy, and the result was normalized to the myocyte DNA content of the corresponding culture plate from which the medium was harvested.

Second, the identity of the trophic factor(s) in the myocyteconditioned medium was addressed by the addition of a specific neutralizing anti-bFGF antibody $(10 \mu \mathrm{g} / \mathrm{ml}$; American Diagnostica Inc., Greenwich, CT) or a nonspecific rabbit polyclonal IgG preparation $(10 \mu \mathrm{g} / \mathrm{ml}$, rabbit reagent grade $\mathrm{IgG}$; No. I5006; Sigma Chemical Co.). In these experiments, FCS (10\% vol/vol) added to the defined medium served as a positive control growth stimulus.

Third, bFGF release was measured directly by ELISA by one co-author (P. L. McNeil) who was blinded to the experimental group of origin of each conditioned medium sample. After $24 \mathrm{~h}$ of culture, heparin $(10 \mu \mathrm{g} / \mathrm{ml})$ was added to each flask for $15 \mathrm{~min}$, after which the myocyte-conditioned medium was collected, centrifuged to remove nonadherent cells and cellular debris, and maintained at $4^{\circ} \mathrm{C}$ in the presence of $5 \mu \mathrm{g} / \mathrm{ml}$ aprotinin, $5 \mu \mathrm{g} / \mathrm{ml}$ leupeptin, $1 \mu \mathrm{g} / \mathrm{ml}$ pepstatin, and $1 \mathrm{mmol} / \mathrm{L}$ phenylmethylsulfonyl fluoride. ELISA measurements were performed with a kit, according to the manufacturer's instructions (bFGF ELISA kit; Wako Bioproducts, Richmond, VA). The amount of bFGF was determined by comparison with a standard curve constructed on the same 96-well plate by using purified recombinant human bFGF.
Fluorescein-dextran incorporation by continually paced myocytes

To test the hypothesis that transient alterations in sarcolemmal permeability could facilitate release of cytosolic bFGF during beating, isolated ventricular myocytes were electrically stimulated in defined medium containing $2.5 \mathrm{mg} / \mathrm{ml}$ fluorescein-labeled dextran. Dextran (mol wt 10,000; Sigma Chemical Co.) was labeled with fluorescein as previously described (34). After continual uniform field stimulation for 24,48 , or $72 \mathrm{~h}$, uptake of the labeled compound was assessed by FACS $^{\circledR}$. Paced and quiescent control myocytes plated directly onto tissue culture flasks were removed by gentle trypsinization $(2 \%$ trypsin, $50 \mathrm{mM}$ EDTA; Sigma Chemical Co.). The detached cells were collected by centrifugation and then washed twice with defined medium to remove excess fluorescein-labeled dextran. Well-mixed aliquots were then examined by FACS ${ }^{\circledR}$ to determine the relative fluorescence of each treatment group. Each FACS ${ }^{\circledR}$ run examined $\sim 10,000$ cells.

\section{Statistical analysis}

All data are presented as means \pm SEM. Comparisons between groups were performed by unpaired Student's $t$-test or Mann-Whitney $U$ test for data that were not normally distributed. Analysis of variance was used to identify differences among multiple groups, and post hoc analysis was performed by Scheffe's test. The null hypothesis was rejected at $P<0.05$.

\section{Results}

Effects of continual electric field pacing on adult ventricular myocyte phenotype. Stimulation of contractile activity by continuous uniform electrical field stimulation was associated with marked alterations in cellular phenotype and growth after $96 \mathrm{~h}$ of isolation and plating. For the first $48-72 \mathrm{~h}$ after initiation of pacing, although some alterations in myocyte electromechanical function have been documented previously (31), there were no marked changes in cell morphology or size compared with parallel control cultures of nonpaced adult ventricular myocytes also maintained in defined medium, although some paced cells exhibited rounding at the cell ends. As previously noted $(31,32)$, when cells were allowed to "recover" for a minimum of $6 \mathrm{~h}$ after isolation before initiation of the pacing protocol, there was no difference in cell survival or in the percentage of rod-shaped cells (i.e., $\sim 70-75 \%$ of cells) at $72 \mathrm{~h}$.

By the fourth day in culture, however, many paced myocytes began to lose their cylindrical, rod-shaped appearance, sending out "ruffles" or pseudopod-like extensions from the ends, and to spread on the culture plate (Fig. 1). After $96 \mathrm{~h}$ of stimulation, as shown in Fig. 2, electrically paced myocytes were $37 \%$ larger in area than quiescent controls followed for the same time interval $(5,604 \pm 251$ vs $4,082 \pm 153$ pixels, respectively; $n=54$ and 53 cells; $P<0.05$ ). This growth response associated with contractile activity was also reflected by an increase in phenylalanine incorporation, as estimated by the rate of radiolabeled phenylalanine incorporation, and by an increase in total protein content normalized to DNA content. After $24 \mathrm{~h}$ in culture, $\left[{ }^{3} \mathrm{H}\right]$ phenylalanine incorporation was significantly greater in paced, contracting myocytes compared with nonpaced controls (Fig. $3 a$ ). Electrically paced myocytes also had a significantly higher total protein content normalized to DNA content than quiescent control cells (Fig. $3 b$ ).

Role of bFGF in mediating the hypertrophic response to continual pacing. bFGF is among the trophic factors known to be present or synthesized by cardiac myocytes. Exogenous $\mathrm{rhbFGF}(10 \mathrm{ng} / \mathrm{ml})$ caused an increase in the size of quiescent 

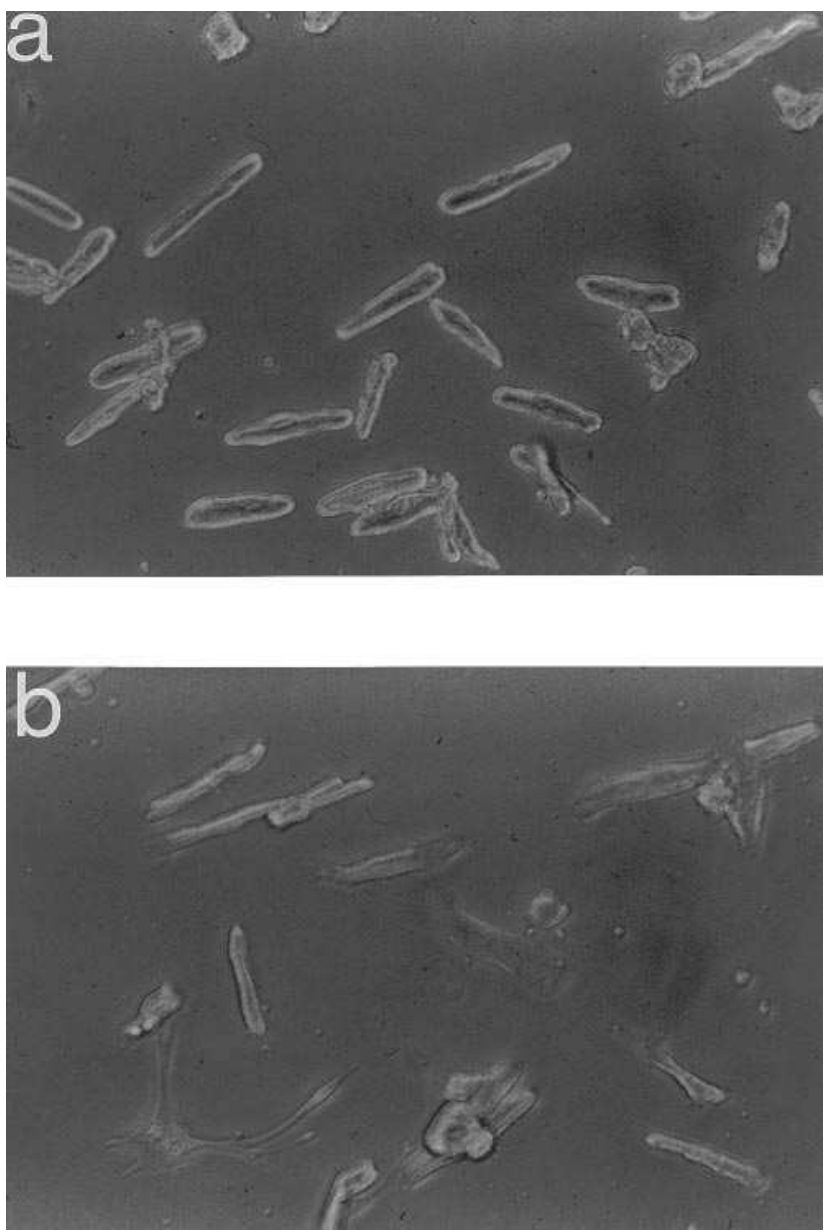

Figure 1. Continual pacing induces alterations in adult rat ventricular myocyte phenotype. Unlike nonpaced, quiescent primary isolated adult cardiac myocytes maintained in serum-free defined medium $(a)$, myocytes maintained in the same medium that have been continually paced at $3 \mathrm{~Hz}$ after $72 \mathrm{~h}$ begin to exhibit morphologic changes that include an increase in cell size, manifested initially as the formation of membrane ruffles at the ends of the cells at the sites of the former intercalated disks, followed by generalized cell spreading $(b)$. Both phase-contrast photomicrographs were taken after $96 \mathrm{~h}$ in culture at $\times 100$.

nonpaced myocytes at $96 \mathrm{~h}(5,225 \pm 208.8$ pixels; $n=65$ cells $)$ that was not significantly different from that observed in paced cells maintained in defined medium alone (Fig. 2). Exogenous bFGF increased by over threefold the rate of $\left[{ }^{3} \mathrm{H}\right]$ phenylalanine incorporation in nonpaced quiescent myocytes (Fig. $3 a$ ) and also resulted in a significant increase in total protein content normalized to DNA at $24 \mathrm{~h}$ (Fig. 3 b).

To test the hypothesis that the hypertrophic response of myocytes exposed to continual electrical stimulation was mediated by an increased release of bFGF, the rate of [ $\left.{ }^{3} \mathrm{H}\right]$ phenylalanine incorporation and changes in total cellular protein content were determined in paced cells in the presence of either a neutralizing rabbit anti-bFGF polyclonal $\mathrm{IgG}$ preparation or a nonspecific rabbit polyclonal IgG added to the defined medium. Although there was a trend towards a reduction in $\left[{ }^{3} \mathrm{H}\right]$ phenylalanine incorporation into paced cells treated with anti-bFGF antisera compared with paced cells incubated with the nonspecific control IgG preparation, this did not reach sta-
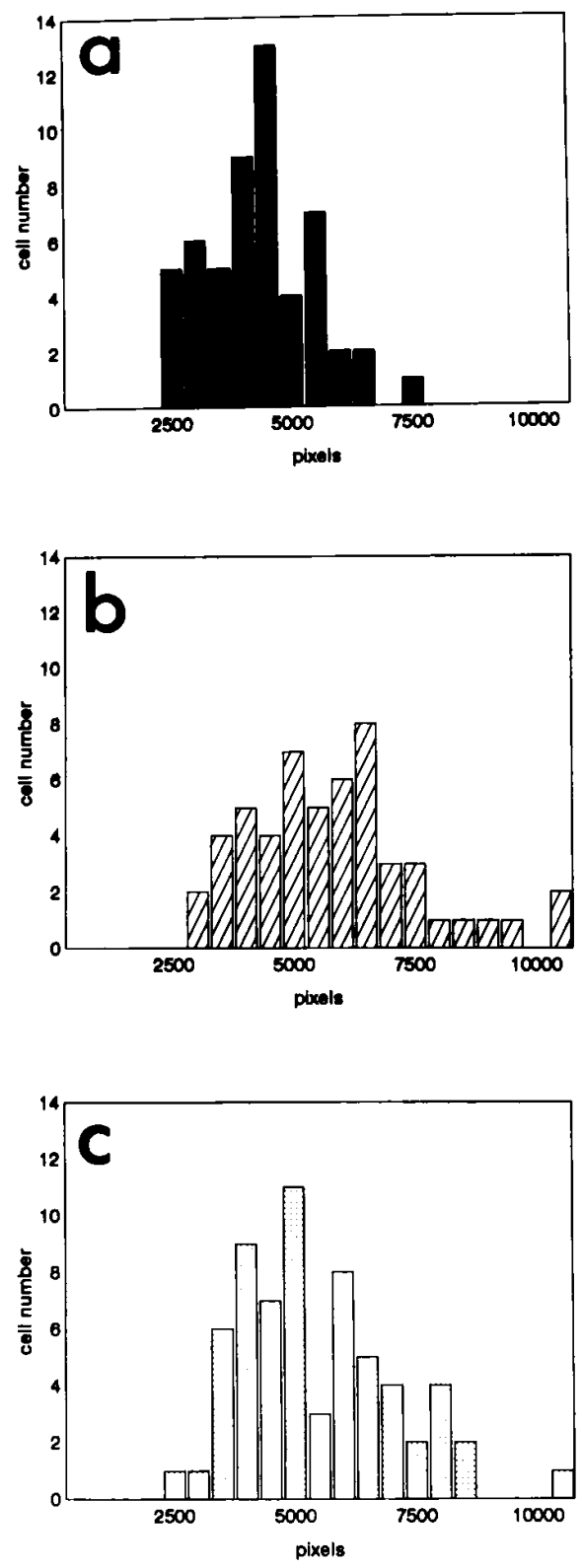

Figure 2. Continual pacing and exogenous rhbFGF increase cardiac myocyte size as assessed by digital imaging microscopy. Control, quiescent adult rat ventricular myocytes were cultured in defined medium alone or in the presence of $\operatorname{rhbFGF}(10 \mathrm{ng} / \mathrm{ml})(c)$ for a period of $96 \mathrm{~h}$, and their rate of growth was compared with that of parallel cultures of either quiescent control adult rat ventricular myocytes in defined medium $(a)$ or myocytes that were continually paced at $3 \mathrm{~Hz}$ (b). The medium was changed every $24 \mathrm{~h}$ in the three experimental groups. The two-dimensional size of each cell examined was determined by phase-contrast microscopy and digital imaging software operated by an observer blinded to the experimental group of origin of each cover slip examined. 50-60 cells from three separate experiments were examined in each experimental group.

tistical significance (i.e., $P=0.07$; Fig. $3 a$ ). However, protein content normalized to DNA was significantly reduced at $24 \mathrm{~h}$ by the anti-bFGF IgG as shown in Fig. $3 b$.

The neutralizing capacity of the anti-bFGF IgG preparation was supported by separate experiments in which the $\left[{ }^{3} \mathrm{H}\right]$ phenylalanine incorporation rate was reduced in non- 

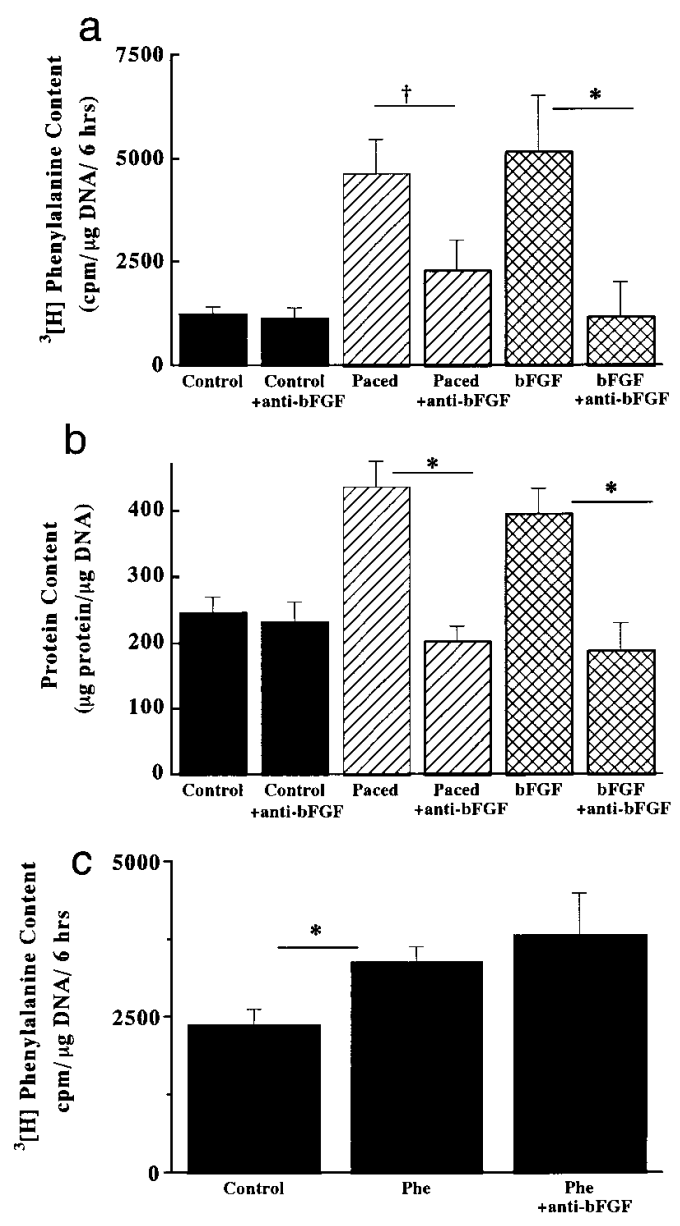

Figure 3. Continual pacing and rhbFGF increase $\left[{ }^{3} \mathrm{H}\right]$ phenylalanine uptake and total cellular protein content in cardiac myocytes: effect of anti-bFGF-specific IgG. (a) $\left[{ }^{3} \mathrm{H}\right]$ phenylalanine incorporation, measured over $6 \mathrm{~h}$ and normalized to DNA content, was examined after $24 \mathrm{~h}$ in control, quiescent myocytes and in continually paced myocytes and in quiescent control myocytes exposed to $10 \mathrm{ng} / \mathrm{ml}$ rhbFGF in the absence or presence of rabbit polyclonal anti-bFGF IgG (mean \pm SEM from 4-11 flasks in each group from at least four experiments). Both paced and rhbFGF-treated cells had significantly higher rates of $\left[{ }^{3} \mathrm{H}\right]$ phenylalanine incorporation than control cells $(P<0.01)$. Anti-bFGF IgG prevented the increase in $\left[{ }^{3} \mathrm{H}\right]$ phenylalanine uptake by rhbFGF $(* P<0.05)$ and slowed the rate of $\left[{ }^{3} \mathrm{H}\right] \mathrm{phe}-$ nylalanine uptake in paced cells $(\dagger P=0.07)$. (b) Total protein content was also determined at $24 \mathrm{~h}$ and normalized to DNA content in the same three experimental groups noted in $a$. (Mean \pm SEM of 7-13 flasks in each group from seven separate experiments.) Paced and rhBFGF-treated cells had significantly higher protein contents than quiescent control cells $(P<0.05)$. Anti-bFGF IgG significantly blunted the increase in protein content at $24 \mathrm{~h}$ in paced and rhbFGFtreated myocytes $(* P<0.05)$. (c) Phenylephrine $(10 \mu \mathrm{M})$ significantly increased the rate of $\left[{ }^{3} \mathrm{H}\right]$ phenylalanine uptake in quiescent control cells at $24 \mathrm{~h}(n=$ three plates; $* P<0.05)$. The anti-bFGF IgG had no effect on the increased rate of $\left[{ }^{3} \mathrm{H}\right]$ phenylalanine incorporation after phenylephrine.

paced quiescent myocytes treated with both rhbFGF and bFGFspecific IgG (Fig. 3 a). A nonspecific rabbit polyclonal $\operatorname{IgG}$ preparation used at the same concentration as the neutralizing anti-bFGF IgG had no effect on the growth response of quiescent adult ventricular myocytes exposed to rhbFGF $(4,845 \pm$ $1,403 \mathrm{cpm} / \mu \mathrm{g}$ DNA per $6 \mathrm{~h} ; n=$ three flasks from two separate experiments). This nonspecific rabbit IgG preparation had no effect on the rate of $\left[{ }^{3} \mathrm{H}\right]$ phenylalanine incorporation in either quiescent control myocytes or continually paced myocytes (data not shown).

Measurements of total protein content normalized to DNA content in cells treated with rhbFGF and either the specific bFGF neutralizing antibody or a nonspecific Ig were also consistent with these data. As expected, the anti-bFGF-specific antibody prevented an increase in total protein content in quiescent, nonpaced myocytes exposed to $10 \mathrm{ng} / \mathrm{ml} \mathrm{rhbFGF}$ (Fig. $3 b$ ), whereas the polyclonal rabbit IgG had no effect ( $388 \pm 93$ $\mathrm{mg} / \mu \mathrm{g}$ DNA; $n=$ three plates). As with $\left[{ }^{3} \mathrm{H}\right]$ phenylalanine uptake, there was no significant effect of the nonspecific polyclonal IgG on total protein content in control, quiescent myocytes or in continually paced myocytes.

To verify that the polyclonal anti-bFGF IgG did not inhibit the growth response of adult rat ventricular myocyte preparations to other hypertrophic stimuli, quiescent nonpaced myocytes were exposed to the $\alpha$-adrenergic agonist phenylephrine $(10 \mu \mathrm{M})$ in the absence or presence of the bFGF-specific antibody preparation. As shown in Fig. $3 c$, the rate of $\left[{ }^{3} \mathrm{H}\right]$ phenylalanine incorporation was higher in phenylephrine-treated myocytes regardless of whether the anti-bFGF IgG were present. As with the response of quiescent cells to rhbFGF, there was no effect of the nonspecific IgG preparation on the growth response of quiescent cells to phenylephrine.

Continual pacing induces myocyte release of $b F G F$. These data suggested that at least part of the hypertrophic response of adult ventricular myocytes to a continual pacing stimulus was due to bFGF. To determine whether there was evidence for bFGF release into the extracellular matrix or medium, Swiss $3 \mathrm{~T} 3$ cells were exposed to defined medium conditioned by either control or by electrically stimulated myocytes for $24 \mathrm{~h}$. As shown in Fig. $4 a$, 3T3 cells exposed to defined medium conditioned by continually paced cells demonstrated significantly greater thymidine uptake than medium conditioned by quiescent myocytes. The magnitude of this increase was approximately equivalent to the nearly threefold increase observed with $10 \%$ FCS, as a positive control. Evidence that this mitogenic activity was due in part to the presence of bFGF was provided by experiments in which the addition of the neutralizing anti-bFGF antibody to the mitogenic assay system significantly reduced the stimulatory effects of medium conditioned by paced myocytes, whereas a control nonspecific polyclonal Ig fraction did not significantly lower the rate of 3T3 cell thymidine uptake (Fig. $4 b$ ). The addition of either the neutralizing anti-bFGF or nonspecific polyclonal $\mathrm{IgG}$ preparations to culture medium conditioned by quiescent myocytes also failed to alter significantly the uptake of labeled thymidine (Fig. $4 c$ ). In addition, neither Ig preparation had any effect on the rate of $\left[{ }^{3} \mathrm{H}\right]$ thymidine incorporation into $3 \mathrm{~T} 3$ cells incubated in $10 \%$ FCS (data not shown).

To confirm the presence of bFGF in the medium conditioned by paced myocytes, bFGF was measured directly by ELISA. The bFGF concentration in the medium of quiescent, control myocytes $24 \mathrm{~h}$ after plating was at or below the limit of detection of the assay $(9.9 \pm 2.9 \mathrm{pg} / \mathrm{ml} ; n=$ three flasks $)$. The bFGF concentration in electrically paced myocyte-conditioned medium that also contained $10 \mathrm{mM} \mathrm{2,3-butanedione} \mathrm{mon-}$ oxime (BDM) to slow cross-bridge cycling and inhibit excitation-contraction coupling also had little or no detectable $\mathrm{bFGF}$ at $24 \mathrm{~h}(3.1 \pm 3.0 \mathrm{pg} / \mathrm{ml} ; n=$ three flasks $)$. In contrast, the 
bFGF content of medium conditioned by paced myocytes in the absence of BDM at $24 \mathrm{~h}$ was $977 \pm 36 \mathrm{pg} / \mathrm{ml}(n=$ two flasks).

Effects of pacing on the rate of fluorescein-dextran uptake into cardiac myocytes. To determine whether continual con-
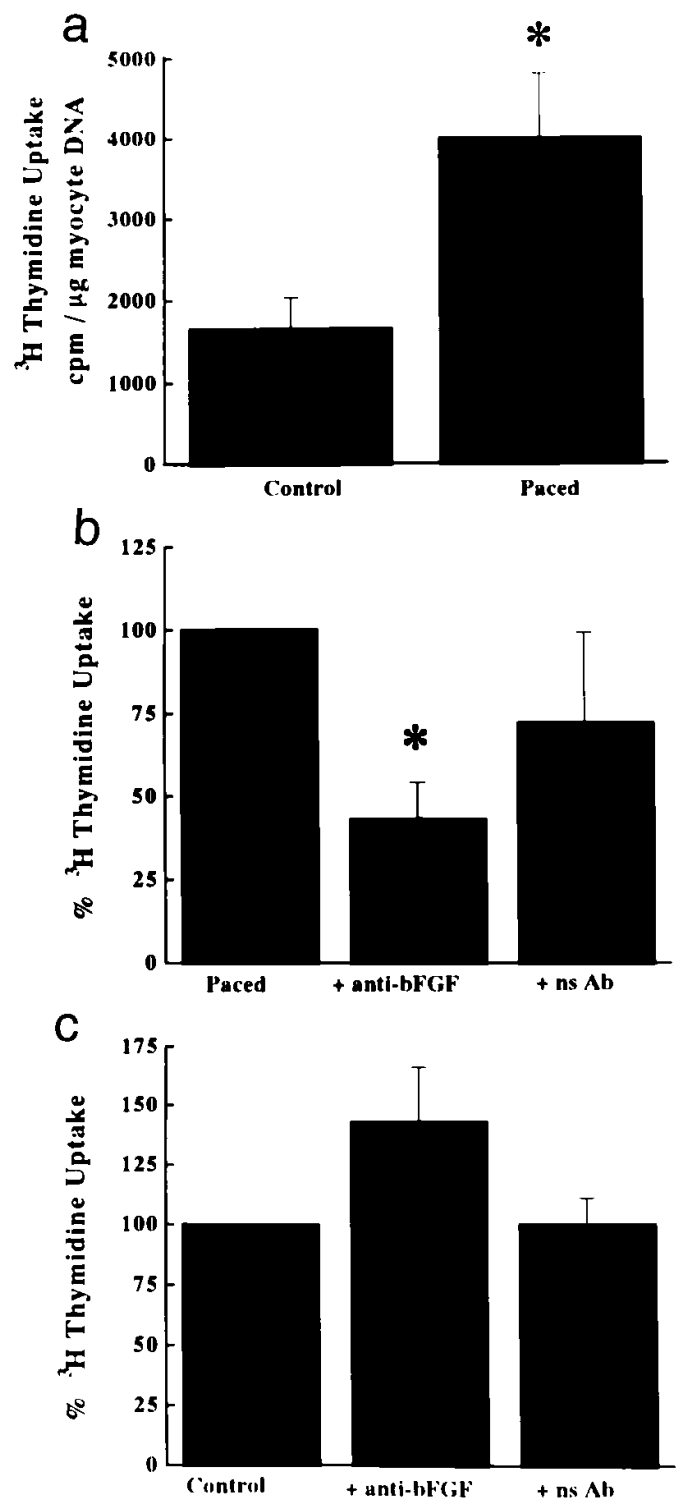

Figure 4. Medium conditioned by continually paced ventricular myocytes increases $\left[{ }^{3} \mathrm{H}\right]$ thymidine uptake into $3 \mathrm{~T} 3 \mathrm{cells}$. (a) Defined medium conditioned by either quiescent control or continually paced cardiac myocytes for $24 \mathrm{~h}$ was harvested after the addition of heparin sulfate $(10 \mu \mathrm{g} / \mathrm{ml})$ and aliquots were placed on subconfluent $3 \mathrm{~T} 3$ cells maintained in DMEM with $0.5 \%$ FCS. The $\left[{ }^{3} \mathrm{H}\right]$ thymidine incorporation over $24 \mathrm{~h}$ normalized to the DNA content of the myocyte culture from which the medium was harvested is shown (mean \pm SEM of 12 samples from three independent experiments; $* P<0.01)$. The effects of a neutralizing specific anti-bFGF antibody or a nonspecific Ig preparation were examined on the $\left[{ }^{3} \mathrm{H}\right]$ thymidine uptake over $24 \mathrm{~h}$ into $3 \mathrm{~T} 3$ cells incubated in medium conditioned by paced cells $(b)$ or quiescent cells (c). In both $b$ and $c$, the data for both the anti-bFGF neutralizing antibody and the nonspecific Ig preparation have been expressed as a percentage of the $\left[{ }^{3} \mathrm{H}\right]$ thymidine uptake into $3 \mathrm{~T} 3$ cells exposed to medium conditioned by paced and by quiescent control cells, respectively. (Mean $\pm \mathrm{SEM} ; n=4-6$ replicates in each group from three independent experiments; ${ }^{*} P<0.05$ ). tractile activity could induce alterations in membrane permeability that could facilitate the release of cytosolic bFGF, adult rat ventricular myocyte primary isolates were paced in defined medium containing fluorescein-labeled dextran (mol wt $\sim 10,000 \mathrm{kD})$. Both paced and nonpaced cells exhibited uptake of fluorescein-dextran when examined after 24 and $48 \mathrm{~h}$, as shown in the representative photomicrographs in Fig. 5, $c$ and $d$. Fluorescein-dextran uptake into paced cells was greater at $72 \mathrm{~h}$ compared with quiescent control cells and appeared to be homogeneously distributed, consistent with uptake into the cytosol. In contrast, uptake into quiescent control cells at $72 \mathrm{~h}$ was less intense and exhibited a punctate distribution consistent with pinocytotic uptake of the fluorescently labeled dextran and compartmentation within the cell. The phase-contrast photomicrographs of these cells (Fig. 5, $a$ and $b$ ) also demonstrate the rounding at the cell ends that is characteristic of some paced cells at $48 \mathrm{~h}$ compared with the consistent rodshaped morphology of quiescent cells.

Paced myocytes exhibited a consistently higher mean cellular fluorescence at 24 and $48 \mathrm{~h}$, as assessed by FACS ${ }^{\circledR}$, than control quiescent myocytes that had also been incubated in medium containing fluorescein-labeled dextran (Fig. 6, $a$ and $b$, respectively). A gradual, but much slower, increase in fluorescein-dextran uptake was also apparent in quiescent cells
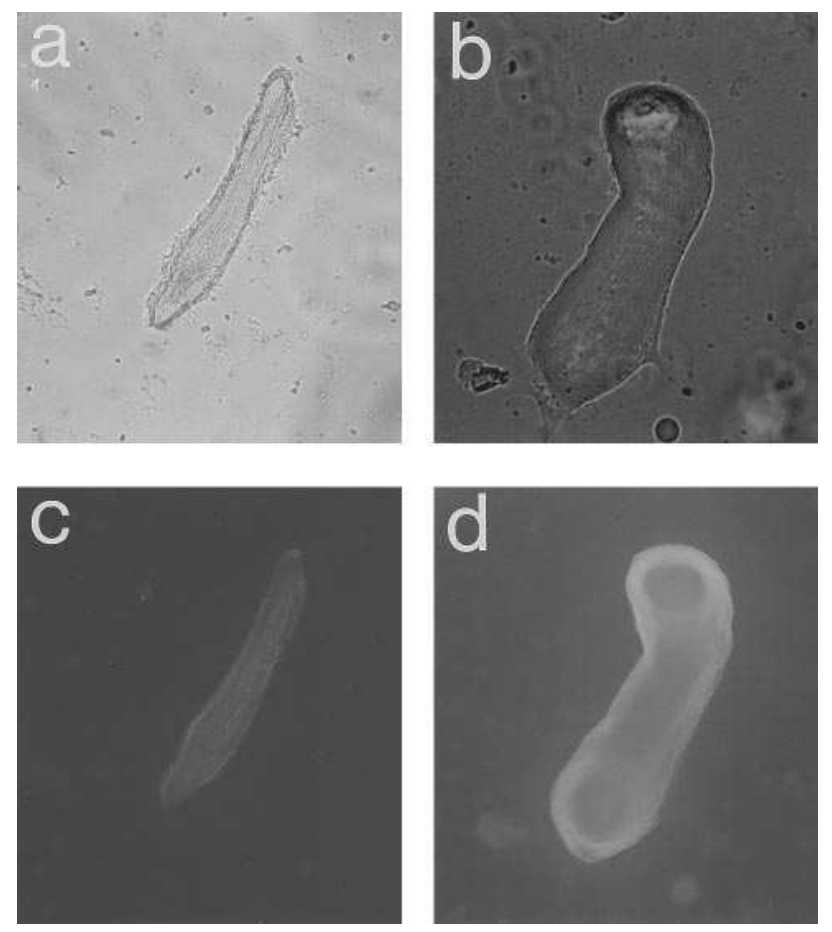

Figure 5. Fluorescein-dextran uptake into quiescent and continually paced adult ventricular myocytes. A phase-contrast photomicrograph of $(a)$ quiescent control and $(b)$ continually paced $(3-\mathrm{Hz})$ adult rat ventricular myocytes maintained in a defined medium containing 2.5 $\mathrm{mg} / \mathrm{ml}$ of fluorescein-labeled dextran $(10 \mathrm{kD}) 72 \mathrm{~h}$ after isolation and initiation of primary cultures. Quiescent cells retain their rod-shaped appearance, whereas continually paced myocytes exhibit early evidence of cell growth and spreading at the sites of the intercalated disks. Fluorescence photomicrographs of the $(c)$ quiescent control cell and $(d)$ continually paced myocyte illustrated in $a$ and $b$ are also shown. Fluorescein-dextran uptake into the paced cells exhibits a more uniform, homogeneous appearance consistent with cytosolic localization compared with the rod-shaped, nonpaced cell. $\times 400$. 
over time. The difference in fluorescent intensities of paced and control quiescent cells ranged from $\sim 50$-fold (Fig. $6 a$ ) to threefold (Fig. $6 \mathrm{c}$ ) and varied among primary cultures and among different batches of fluorescein-labeled dextran.

To determine whether mechanical activity was required in addition to membrane depolarization to facilitate fluoresceindextran uptake, the L-type $\mathrm{Ca}^{2+}$ channel antagonist verapamil $(10 \mu \mathrm{M})$ was used to prevent $\mathrm{Ca}^{2+}$-induced sarcoplasmic reticulum $\mathrm{Ca}^{2+}$ release and contraction. As shown in Fig. $6 c$, verapamil consistently reduced the rate of fluorescein uptake into myocytes exposed to continual uniform electric field stimulation below that observed in quiescent control cells. Addition of $10 \mathrm{mM}$ BDM also prevented an accelerated rate of fluorescein-dextran uptake in paced cells at $24 \mathrm{~h}$ that was not different from that observed in quiescent control cells in one experiment (data not shown).

\section{Discussion}

Continual pacing and cardiac myocyte phenotypic adaptation to primary culture. Postmitotic adult ventricular myocytes have not been amenable to long-term primary culture unless maintained in serum-containing medium. As originally described by Claycomb and Palazzo (35), these cells undergo a sequence of phenotypic adaptations that includes a loss of their rod-shaped morphology and an increase in cell size, the reexpression of a number of fetal genes including atrial natriuretic peptide (36), and, eventually, spontaneous contractile activity. Quiescent, freshly isolated adult ventricular myocytes can be maintained in defined medium for $\sim 10-14 \mathrm{~d}$ before the majority of cells begins to atrophy and subsequently to undergo irreversible contraction, cell detachment, and death, although a decline in contractile responsiveness to electrical pacing can be detected within $24 \mathrm{~h}$ (31). Initiation of continual uniform electric field pacing at physiologically relevant frequencies $(\geq 3 \mathrm{~Hz})$ can mitigate some of the decline in contractile function noted in quiescent cells, and it was anticipated that this technique would permit less atrophy and longer survival for adult cardiac myocytes maintained in defined medium $(31,32)$.

As we have described previously, there are no gross morphologic differences between paced myocytes continually paced at $3 \mathrm{~Hz}$ and control quiescent cells maintained in defined medium until $48 \mathrm{~h}$. However, by $96 \mathrm{~h}$, the majority of continuously paced cells had undergone a visible shift in phenotype, increasing in cell size and exhibiting formation of pseudopodlike structures or ruffles emerging from the regions of the intercalated disks at the cell ends (Fig. 1). Similar changes in cell morphology have recently been reported in adult feline ventricular myocytes continually paced at $1 \mathrm{~Hz}$ for $7 \mathrm{~d}$ in defined
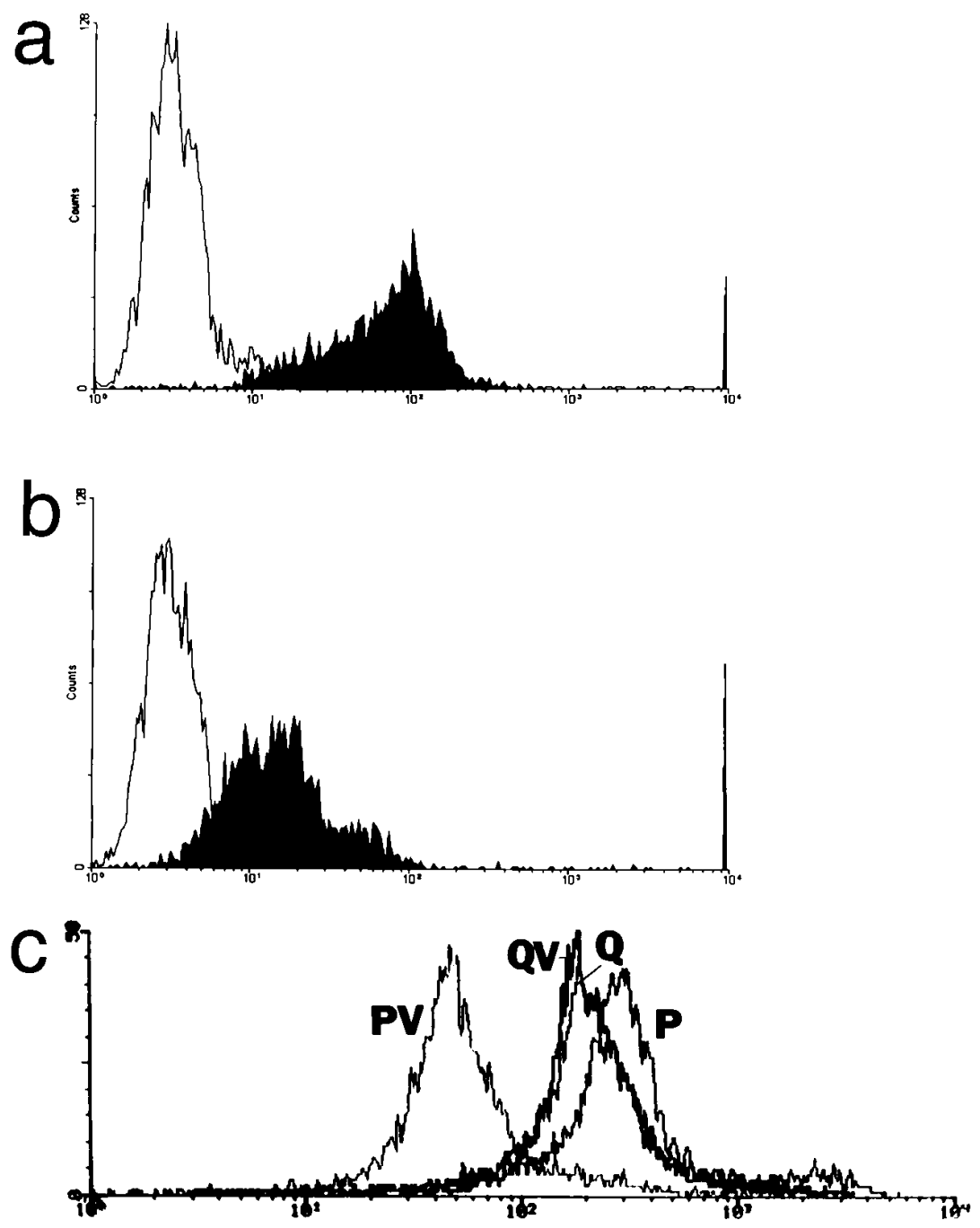

Figure 6. FACS ${ }^{\circledR}$ analysis of fluorescein-labeled dextran uptake into paced and quiescent ventricular myocytes. (a) Continually paced adult rat ventricular myocytes (shaded curves) and control quiescent cells (open curves) were maintained for $24(a)$ and $48 \mathrm{~h}(b)$ in defined medium containing fluorescein-labeled dextran (average mol wt 10,000). After several washes, the cells were harvested from the tissue culture plate and analyzed by FACS ${ }^{\circledR}$. (c) Continually paced myocytes were incubated in the presence and absence of $10 \mu \mathrm{M}$ verapamil and fluoresceinlabeled dextran for $48 \mathrm{~h}$ before harvesting for FACS $^{\circledR}$ analysis. $P$, paced myocytes; $P V$, paced myocytes with verapamil; $Q$, quiescent myocytes; $Q V$, quiescent myocytes with verapamil. The two quiescent myocyte curves (i.e., $\mathrm{Q}$ and QV curves) largely overlap. Arbitrary fluorescence units are shown on the abscissa and cell number on the ordinate. Approximately 10,000 cells were analyzed per FACS ${ }^{\circledR}$ run. These experiments were performed three times (at 24 and $48 \mathrm{~h}$ ) with similar results. 
serum-free medium (37). These changes were unexpected (by us) and resembled the early stages of phenotypic adaptation of quiescent adult ventricular myocytes cultured in serum-containing medium (i.e., at $24-48 \mathrm{~h}$ after isolation) $(35,38,39)$. Since these primary adult ventricular myocyte cultures contain $<5 \%$ nonmyocyte cells (31), the paced myocytes themselves were the likely source of any mitogenic or growth-promoting activity present in the extracellular matrix or medium.

In vitro models of cardiac myocyte hypertrophy. A number of in vitro techniques have been described that model myocyte growth responses to hypertrophic stimuli. These usually have been based upon the administration of trophic agents such as $\alpha$ - and $\beta$-adrenergic receptor agonists (4-9), angiotensin II (11, $40,41)$, endothelins $(42,43)$, FGFs $(10,22,24,25)$, or insulinlike growth factor-1 (44). While many of these serve as useful cellular models, with the possible exceptions of catecholamineinduced hypertrophy and that associated with hyperthyroidism or acromegaly, their relevance to ventricular hypertrophy in vivo, particularly in the context of increased mechanical stress or load, remains to be determined.

Passive stretch alone has also been shown to trigger several signal transduction pathways that result in hypertrophic adaptation in neonatal rat and adult feline cardiocytes $(1,45-$ 47). This paradigm for modeling the growth-promoting and mitogenic effects of cell stretch or increased shear stress has been confirmed in other cells exposed to external loads, including fibroblasts (48), endothelial cells (16), skeletal muscle (49), and vascular smooth muscle cells (50). In spontaneously beating neonatal and ventricular myocyte cultures, and in neonatal and adult rat ventricular myocyte preparations that are paced using an electric field stimulation technique, the importance of mechanical activity for hypertrophic adaptation, as opposed to repetitive sarcolemmal membrane depolarization without electromechanical coupling, has also been demonstrated. McDermott and colleagues $(37,51)$ have demonstrated that continually paced adult feline ventricular myocytes exhibit an increase in protein synthesis and content, and that uncoupling of membrane depolarization from mechanical contraction, using either verapamil or BDM, an agent that interrupts $\mathrm{Ca}^{2+}$-induced activation of cross-bridge interactions, prevents both an acceleration of protein synthesis and an increase in myocyte ribosomal RNA content. Kubisch et al. (52) have also reported that increased immediate early gene transcription in adult ventricular myocytes induced by continual pacing could also be prevented by BDM. Importantly, Kato et al. (37) also report that, whereas a small decline $(\sim 15 \%)$ in protein synthesis rates and total cellular protein content could be detected in quiescent myocytes during the first week of primary culture, both protein synthesis rates and total cellular protein content were significantly higher (by 40-50\%) in paced compared with control myocytes. These data indicate that, whereas a limited degree of atrophy does occur over $1 \mathrm{wk}$ in quiescent cells, there is a significant amount of hypertrophic growth in paced cells.

The link between mechanical activity and hypertrophy, therefore, is well established. However, the mechanism(s) by which changes in mechanical force are transduced into intracellular signaling events responsible for hypertrophy in the myocardium are unclear. Sadoshima et al., in studies of neonatal rat myocyte primary cultures, excluded an important role for stretch-activated ion channels in mediating the induction of immediate early gene expression in passively stretched neona- tal rat myocytes (53). Using cytochalasin D and colchicine, these authors also excluded a role for actin myofilaments and microtubules in mediating immediate early gene activation with passive mechanical stress. These cytochalasin D data may also exclude an important role for activation of focal adhesion kinase (pp125FAK) in transducing changes in stress-induced cell attachment to cell growth (54), at least in neonatal rat cardiac myocytes.

In a subsequent report, Sadoshima and co-authors provided evidence that the hypertrophic response of cardiac myocytes to stretch was mediated by a trophic factor released into myocyte-conditioned medium that appeared to act as an extracellular autocrine/paracrine growth signal (47). This conclusion was drawn from experiments that demonstrated that culture medium conditioned by neonatal cardiac myocytes undergoing passive stretch was able to induce c-fos expression in nonstretched myocytes. This c-fos-inducing activity was demonstrable in stretched myocyte-conditioned medium with periods of stretch as short as $1 \mathrm{~min}$. Using a variety of c-fosCAT reporter constructs designed around the serum response element and calcium/cAMP response element of the c-fos promoter, they also demonstrated that the serum response element was an important final common site for the induction of c-fos by stretch (47). This finding is consistent with that of others who have observed a link between stretch-induced hypertrophy and activation of one or more protein kinase Cs and MAPKs (55).

bFGF and cardiac myocyte growth. Members of the FGF family of signaling peptides, including aFGF and bFGF, are known to be important morphogens and growth regulators during cardiac ontogeny $(23,26,56-58)$. Although both aFGF and bFGF are present within adult cardiac muscle, their importance in regulating the growth and phenotype of cardiac myocytes and other cellular components of cardiac muscle in postnatal development is not well understood.

Both bFGF and aFGF can be detected in freshly isolated adult rat ventricular myocytes by immunohistochemistry, by Western analysis, and by immunoassay of mitogenic activity detected in myocyte cell lysates processed by heparin-Sepharose affinity chromatography (19-22, 59). In the intact heart, we have documented increased release by ELISA of both bFGF and aFGF in the perfusate of adult rat hearts retrogradely perfused for 5 min ex vivo in a Langendorff preparation with a physiologic saline solution containing $10^{-7} \mathrm{M}$ isoproterenol (60).

In confluent serum-starved neonatal rat ventricular myocytes as well as adult rat ventricular myocytes, addition of exogenous bFGF or aFGF induced activation of MAP kinase kinase (MEKs) as well as both 42- and 44-kD isotypes of MAPK (ERK2/ERK1) (10). Interestingly, exogenous aFGF and bFGF appear to initiate different patterns of contractile protein gene expression in serum-starved neonatal rat cardiac myocytes, at least in terms of $\alpha$-actin isoforms (25). At least one class of FGF receptors, termed Flg (or FGF receptor 1), is present in the sarcolemma of freshly isolated adult rat ventricular myocytes, although receptor number decreases during development (22). Speir et al. noted also that the increase in cell size and the process of phenotypic adaptation of adult rat ventricular myocytes to long-term growth in serum-containing medium is accompanied by increased synthesis of both bFGF and aFGF as well as increased expression of FGF receptor 1 (22).

There are limited data relevant to the role of endogenous FGF peptides in the developed myocardium. Padua and Kar- 
dami (59) demonstrated a doubling of bFGF protein content in rat hearts after a single exposure to a high but sublethal intraperitoneal injection of isoproterenol. This was due primarily to an increase in the $18-\mathrm{kD}$ bFGF isoform that was apparent within $24 \mathrm{~h}$ and sustained for as long as $6 \mathrm{wk}$. They also noted a transient increase in the content of $21-23-\mathrm{kD}$ isoforms that peaked at $24 \mathrm{~h}$. Particularly intense bFGF staining on immunohistochemical analysis was observed surrounding viable myocytes adjacent to fibrotic areas of myocardium at later time points. These authors suggested that increased production of bFGF was part of the adaptive response of the myocardium to injury, which included a reexpression of some fetal proteins in myocytes adjacent to areas of necrosis, as determined by the detection of vimentin in myofibrillar striations (59).

Cardiac myocytes may also be the source of other growth or trophic factors that could act in a paracrine or autocrine manner to regulate myocyte adaptation to mechanical stimuli. Angiotensin II, possibly of myocyte origin, has been implicated in the adaptive response to increased stretch in neonatal rat myocyte primary cultures $(41,61)$. The recent demonstration that expression of angiotensin-converting enzyme is regulated by bFGF in vascular smooth muscle cells suggests a potentially important mechanism linking these two autocrine/ paracrine-acting peptide-signaling factors that may also be relevant to cardiac muscle (62). Continual uniform electric field pacing also results in increased expression of heparin-binding EGF-like growth factor in adult rat ventricular myocytes (63). Addition of exogenous heparin-binding EGF growth factor to primary isolated adult cardiac myocytes does result in an increase in myocyte total protein content. This trophic factor, in addition to aFGF, may have contributed in part to the increase in $3 \mathrm{~T} 3$ cell mitogenic activity in paced myocyte-conditioned medium that could not be reversed by anti-bFGF-specific IgG (Fig. $4 b$ ).

Altered sarcolemmal membrane permeability and $b F G F$ release. In this report, we have examined the hypothesis that mechanical activity induced by uniform electric field pacing causes release of cytosolic bFGF by a process of transient membrane disruptions, or membrane wounding. Altered transient sarcolemmal permeability sufficient to release bFGF was inferred from the increased rate of uptake of fluoresceintagged dextran, a technique developed for monitoring the uptake of macromolecules into cells in vitro (34). It is unlikely that an increase in cellular volume induced by pacing could account for the changes in fluorescein-dextran uptake assessed by FACS $^{\circledR}$ analysis illustrated in Fig. 6. This is because we quantitated fluorescein-dextran uptake in cells after only 24 or $48 \mathrm{~h}$ of pacing, time points at which we have not detected any change in cell size by digital imaging microscopy or any morphologic changes in myocyte phenotype. It is unlikely that continuous exposure to the alternating polarity electric field or to repetitive cellular depolarization alone were responsible for the release of bFGF and the phenotypic changes observed in paced, beating myocytes, since verapamil-treated myocytes exposed to continual uniform electric field pacing had a rate of fluorescein-labeled dextran uptake that was significantly less than that of paced cells. Also, electrically stimulated verapamil-treated myocytes never exhibited morphologic changes, such as formation of membrane ruffles, that are characteristic of non-verapamil-treated paced myocytes after $48-72 \mathrm{~h}$ in culture. These data are consistent with the observations of Ivester and colleagues (51) that interruption of electromechanical coupling by BDM also prevents immediate early gene transcription and protein synthesis in electrically paced cardiac myocytes. $10 \mu \mathrm{M}$ BDM also prevented the release of bFGF into paced myocyte-conditioned medium, a concentration that effectively inhibits cross-bridge cycling with relatively little effect on peak concentration of intracellular free $\mathrm{Ca}^{2+}$ of myocyte cardiac transients (64).

It is possible that the sarcolemmal membranes of myocytes in vitro after enzymatic dissociation are more "leaky" than those of myocytes in situ. However, the experimental protocol described here was initiated at least $6 \mathrm{~h}$ after myocyte isolation to permit some recovery from the dissociation procedure to occur. In our experience (31) and in the data reported by Kato et al. (37), neither myocyte viability nor the number of rodshaped cells differed between paced and quiescent cells after 4-7 d of culture. Also, we have tracked the uptake of rat albumin into the beating adult rat heart in situ (60). Using digital imaging analysis of sections of ventricular muscle stained with a horseradish peroxidase-linked anti-rat albumin antibody, there was significantly more albumin uptake in myocytes from hearts exposed to isoproterenol compared with hearts exposed to control buffer alone. This intracellular albumin could be localized to the cytosol by immunogold staining and electron microscopy (60).

The cellular mechanisms regulating the activity of aFGF and bFGF are complex and only partly understood. These two FGFs as well as FGF-9 lack characteristic $\mathrm{NH}_{2}$-terminal signal sequences necessary for translocation of nascent peptides into the endoplasmic reticulum for trafficking through the Golgi apparatus into canonical protein secretory pathways (27). It has been proposed that cell death or plasmalemmal disruption are necessary for release of cytosolic FGFs, which could then act to induce hyperplastic or hypertrophic growth of neighboring cells. However, FGF-9 can be secreted constitutively by some cells in vitro despite the lack of a typical $\mathrm{NH}_{2}$-terminal signal sequence (65). In addition, several members of the FGF group of signaling peptides, including aFGF and bFGF, have also been shown to contain nuclear localization sequences (27). bFGF isoform levels within the cell appear to be posttranscriptionally regulated through the use of alternative translation initiation sites (66). Subcellular localization of bFGF in cardiac myocytes has demonstrated, as in other cell types, that some of the peptide is localized to the nucleus (22). However, Wiedlocha et al. (67) reported that uptake and translocation to the nucleus of an exogenous aFGF fusion protein linked to diphtheria toxin A fragment could induce DNA synthesis, but not cellular proliferation, in a cell line that lacked aFGF receptors but that had diphtheria toxin receptors. Cellular proliferation preceded by tyrosine phosphorylation as well as DNA synthesis required functional cell-surface FGF receptors. As these authors note, some FGF isoforms may use two functionally linked but independent cell signaling systems.

In addition to several in vitro mechanical techniques for loading macromolecules into cultured cells, evidence for sublethal membrane wounding and release of cytosolic bFGF without cell necrosis has been documented in vivo after strenuous or eccentric exercise in skeletal muscle (68). Benzaquen et al. (69) have also shown that sublytic concentrations of the complement C5b-9 complex release a mitogenic activity from human umbilical vein and bovine aortic endothelial cells into their culture medium without evidence of severe cellular injury or cell death. This mitogenic activity could be largely reversed 
by neutralizing anti-bFGF antibodies. Thus, some cells can tolerate transient plasmalemmal membrane disruptions sufficient to allow release of $20-\mathrm{kD}$ cytosolic proteins. Such tolerance may be conferred by specialized molecular mechanisms that facilitate membrane resealing. Steinhardt and colleagues (70), for example, have proposed that transient membrane disruptions may be relatively common events for which repair mechanisms must exist. They monitored the magnitude and rate of fura-2 leakage from sea urchin embryos and from 3T3 fibroblasts after cell membrane puncture and determined that resealing required a threshold concentration of external calcium and participation of regulatory and transport proteins also associated with the exocytosis of neurotransmitters.

Thus, isolated paced ventricular myocytes appear to respond to increased mechanical activity by releasing cytosolic bFGF. Within cardiac muscle in situ in the beating heart, under normal physiologic conditions, an equilibrium must eventually be achieved between bFGF release and degradation and between levels of matrix bFGF accumulation and bFGF receptor number and the activity of downstream signaling pathways in the target cell type(s). With an abrupt or sustained increase in cardiac work, increased sarcolemmal membrane wounding may permit a growing accumulation of bFGF within the matrix that is sufficient to trigger a growth response. The accumulation of bFGF, a potent angiogenic factor, in the extracellular matrix in vivo could also provide a mechanism for coupling an adaptive tissue growth response with an increase in blood supply. This mechanism does not preclude the participation of other systemic, local tissue, and cellular responses to increased physiological stress or work; for example, activation of the sympathetic nervous system or of a local intracardiac reninangiotensin signaling pathway. The data reported here also do not imply that the release of cytosolic FGF isoforms is a universal mechanism for transducing increases in mechanical activity into a growth response, although many different cell types appear to have evolved mechanisms for preventing irreversible cellular injury after transient disruptions in cell membrane permeability sufficient to release molecules the size of bFGF. Nevertheless, these data support the hypothesis that some tissues, such as skeletal and cardiac muscle, not only tolerate these changes in membrane permeability, but may use the membrane perturbations as one means of transducing increases in mechanical activity or stress into a chemical signal, such as bFGF, that facilitates a physiologically appropriate adaptation of cellular phenotype.

\section{Acknowledgments}

This work was supported by a grant R37-HL36141 to T. W. Smith from the National Institutes of Health. D. Kaye is the recipient of an Overseas fellowship from the National Heart Foundation of Australia.

\section{References}

1. Cooper IV, G., R. L. Kent, and D. L. Mann. 1989. Load induction of cardiac hypertrophy. J. Mol. Cell. Cardiol. 21:11-30.

2. Chien, K. R., K. U. Knowlton, H. Zhu, and S. Chien. 1991. Regulation of cardiac gene expression during myocardial growth and hypertrophy: molecular studies of an adaptive physiologic response. FASEB J. 5:3037-3046.

3. Parker, T. G., and M. D. Schneider. 1991. Growth factors, proto-oncogenes, and plasticity of the cardiac phenotype. Annu. Rev. Physiol. 53:179-200.

4. Simpson, P. 1985. Stimulation of hypertrophy of cultured neonatal rat heart cells through an $\alpha_{1}$-adrenergic receptor and induction of beating through an $\alpha_{1}$ - and $\beta_{1}$-adrenergic receptor interaction. Circ. Res. 56:884-894.

5. Waspe, L. E., C. P. Ordahl, and P. C. Simpson. 1990. The cardiac $\beta$-myosin heavy chain isogene is induced selectively in $\alpha_{1}$-adrenergic receptor-stimulated hypertrophy of cultured rat heart myocytes. J. Clin. Invest. 85:1206-1214.

6. Clark, W. A., S. J. Rudnick, J. J. LaPres, L. C. Andersen, and M. C. LaPointe. 1993. Regulation of hypertrophy and atrophy in cultured adult heart cells. Circ. Res. 73:1163-1176.

7. Knowlton, K. U., E. Baracchini, R. S. Ross, A. N. Harris, S. A. Henderson, S. M. Evans, C. C. Glembotski, and K. R. Chien. 1991. Co-regulation of the atrial natriuretic factor and cardiac myosin light chain-2 genes during $\alpha$-adrenergic stimulation of neonatal rat ventricular cells. Identification of cis sequences within an embryonic and a constitutive contractile protein gene which mediate inducible expression. J. Biol. Chem. 266:7759-7768.

8. LaMorte, V. J., J. Thorburn, D. Absher, A. Spiegel, J. H. Brown, K. R. Chien, J. R. Feramisco, and K. U. Knowlton. 1994. $\mathrm{G}_{\mathrm{q}}$ - and ras-dependent pathways mediate hypertrophy of neonatal rat ventricular myocytes following $\alpha_{1}$-adrenergic stimulation. J. Biol. Chem. 269:13490-13496.

9. Clark, W. A., S. J. Rudnick, L. C. Anderson, and J. J. LaPres. 1994. Myosin heavy chain synthesis is independently regulated in hypertrophy and atrophy of isolated adult cardiac myocytes. J. Biol. Chem.. 269:25562-25569.

10. Bogoyevitch, M. A., P. E. Glennon, M. B. Andersson, A. Clerk, A. Lazou, C. J. Marshall, P. J. Parker, and P. H. Sugden. 1994. Endothelin-1 and fibroblast growth factors stimulate the mitogen-activated protein kinase signaling cascade in cardiac myocytes. The potential role of the cascade in the integration of two signaling pathways leading to myocyte hypertrophy. J. Biol. Chem. 269:1110-1119.

11. Sadoshima, J., Z. Qiu, J. P. Morgan, and S. Izumo. 1995. Angiotensin II and other hypertrophic stimuli mediated by $\mathrm{G}$ protein-coupled receptors activate tyrosine kinase, mitogen-activated protein kinase, and 90-kD S6 kinase in cardiac myocytes. The critical role of $\mathrm{Ca}^{2+}$-dependent signaling. Circ. Res. 76:1-15.

12. Sachs, F. 1989. Ion channels as mechanical transducers. In Cell Shape: Determinants, Regulation and Regulatory Role. W. D. Stein and F. Bronner, editors. Academic Press, New York. 63-92

13. Schwartz, M. A. 1993. Spreading of human endothelial cells on fibronectin or vitronectin triggers elevation of intracellular free calcium. J. Cell Biol. 120:1003-1010.

14. Juliano, R. L., and S. Haskill. 1993. Signal transduction from the extracellular matrix. J. Cell Biol. 120:577-585.

15. Fujimoto, T., S. Nakade, A. Miyawaki, K. Mikoshiba, and K. Ogawa. 1992. Localization of inositol 1,4,5-triphosphate receptor-like protein in plasmalemmal caveolae. J. Cell Biol. 119:1507-1513.

16. Davies, P. F., and S. C. Tripathi. 1993. Mechanical stress mechanism. An endothelial paradigm. Circ. Res. 72:239-245.

17. Ingber, D. 1991. Integrins as mechanochemical transducers. Curr. Opin. Cell Biol. 3:841-848.

18. Casscells, W., E. Speir, J. Sasse, K. Klagsbrun, P. Allen, M. Lee, M. Chiba, L. Haggroth, B. Calvo, J. Folkman, and S. E. Epstein. 1990. Isolation and characterization of heparin-binding growth factors from human myocardium. J. Clin. Invest. 85:433-441.

19. Kardami, E., and R. Fandrich. 1989. Basic fibroblast growth factor in atria and ventricles of the vertebrate heart. J. Cell Biol. 109:1865-1875.

20. Sasaki, H., H. Hoshi, Y. M. Hong, T. Suzuki, T. Kato, H. Sasaki, M. Saito, H. Youki, K. Karube, S. Konno, M. Onodera, T. Saito, and S. Aoyagi. 1989. Purification of acidic fibroblast growth factor from bovine heart and its localization in the cardiac myocytes. J. Biol. Chem. 264:17606-17612.

21. Weiner, H. L., and J. L. Swain. 1989. Acidic fibroblast growth factor is expressed by cardiac myocytes in culture and the protein is localized to the extracellular matrix. Proc. Natl. Acad. Sci. USA. 86:2683-2687.

22. Speir, E., V. Tanner, A. M. Gonzalez, J. Farris, A. Baird, and W. Casscells. 1992. Acidic and basic fibroblast growth factors in adult rat heart myocytes. Localization, regulation in culture, and effects on DNA synthesis. Circ. Res. 71:251-259.

23. Engelmann, G. L., C. A. Dionne, and M. C. Jaye. 1993. Acidic fibroblast growth factor and heart development. Role in myocyte proliferation and capillary angiogenesis. Circ. Res. 72:7-19.

24. Mima, T., H. Ueno, D. A. Fischman, L. T. Williams, and T. Mikawa 1995. Fibroblast growth factor receptor is required for in vivo cardiac myocyte proliferation at early embryonic stages of heart development. Proc. Natl. Acad. Sci. USA. 92:467-471.

25. Parker, T. G., K.-L. Chow, R. J. Schwartz, and M. D. Schneider. 1992. Positive and negative control of the skeletal $\alpha$-actin promoter in cardiac muscle. A proximal serum response element is sufficient for induction by basic fibroblast growth factor (FGF) but not for inhibition by acidic FGF. J. Biol. Chem. 267:3343-3350.

26. Jin, Y., K. B. S. Pasumarthi, M. E. Bock, A. Lytras, E. Kardami, and P. A. Cattini. 1994. Cloning and expression of fibroblast growth factor receptor1 isoforms in the mouse heart: evidence for isoform switching during heart development. J. Mol. Cell. Cardiol. 26:1449-1459.

27. Mason, I. J. 1994. The ins and outs of fibroblast growth factors. Cell. 78: $547-552$.

28. McNeil, P. L., L. Muthukrishnan, E. Warder, and P. A. D'Amore. 1989. Growth factors are released by mechanically wounded endothelial cells. J. Cell 
Biol. 109:811-822.

29. McNeil, P. L., and R. Khakee. 1992. Disruptions of muscle fiber plasma membranes: role in exercise-induced damage. Am. J. Pathol. 140:1097-1109.

30. McNeil, P. L. 1993. Cellular and molecular adaptations to injurious mechanical force. Trends Cell Biol. 3:302-307.

31. Berger, H.-J., S. K. Prasad, A. J. Davidoff, D. Pimental, Ø. Ellingsen, J. D. Marsh, T. W. Smith, and R. A. Kelly. 1994. Continual electric field stimulation preserves contractile function of adult ventricular myocytes in primary culture. Am. J. Physiol. 266:H341-H349.

32. Ellingsen, Ø., A. J. Davidoff, S. K. Prasad, H.-J. Berger, J. P. Springhorn, J. D. Marsh, R. A. Kelly, and T. W. Smith. 1993. Adult rat ventricular myocytes cultured in defined medium: phenotype and electromechanical function. Am. J. Physiol. 265:H747-H754.

33. Chomczynski, P., and N. Sacchi. 1987. Single-step method of RNA isolation by acid guanidinium thiocyanate-phenol-chloroform extraction. Anal. Biochem. 162:156-159.

34. McNeil, P. L. 1989. Incorporation of macromolecules into living cells. Methods Cell Biol. 29:153-173.

35. Claycomb, W. C., and M. C. Palazzo. 1980. Culture of the terminally differentiated adult cardiac muscle cell. A light and scanning electron microscope study. Dev. Biol. 80:466-482.

36. Claycomb, W. C. 1988. Atrial natriuretic factor mRNA is developmentally regulated in heart ventricles and actively expressed in cultured ventricular cardiac muscle cells of rat and human. Biochem. J. 255:617-620.

37. Kato, S., C. T. Ivester, M. R. Zile, and P. J. McDermott. 1995. Growth effects of electrically stimulated contraction on adult feline cardiocytes in primary culture. Am. J. Physiol. 268:H2495-H2504.

38. Eid, H., D. M. Larson, J. P. Springhorn, M. A. Attawia, R. C. Nayak, T. W. Smith, and R. A. Kelly. 1992. Role of epicardial mesothelial cells in the modification of phenotype and function of adult rat ventricular myocytes in long-term coculture. Circ. Res. 71:40-50.

39. Bugaisky, K. B., and R. Zak. 1989. Differentiation of adult rat cardiac myocytes in cell culture. Circ. Res. 64:493-500.

40. Sadoshima, J.-I., and S. Izumo. 1993. Molecular characterization of angiotensin II-induced hypertrophy of cardiac myocytes and hyperplasia of cardiac fibroblasts. Critical role of the AT1 receptor subtype. Circ. Res. 73:413423.

41. Sadoshima, J.-I., Y. Xu, H.S. Slayter, and S. Izumo. 1993. Autocrine release of angiotensin II mediates stretch-induced hypertrophy of cardiac myocytes in vitro. Cell. 75:977-984.

42. Ito, H., Y. Hirata, S. Adachi, M. Tanaka, M. Tsujino, A. Koike, A. Nogami, F. Marumo, and M. Hiroe. 1993. Endothelin-1 is an autocrine/paracrine factor in the mechanism of angiotensin II-induced hypertrophy in cultured rat cardiomyocytes. J. Clin. Invest. 92:398-403.

43. Shubeita, H. E., P. M. McDonough, A. N. Harris, K. U. Knowlton, C. C. Glembotski, J. H. Brown, and K.R. Chien. 1990. Endothelin induction of inositol phospholipid hydrolysis, sarcomere assembly, and cardiac gene expression in ventricular myocytes. A paracrine mechanism for myocardial cell hypertrophy. J. Biol. Chem. 265:20555-20562.

44. Donohue, T. J., L. D. Dworkin, M. N. Lango, K. Fliegner, R. P. Lango, J. A. Benstein, W. R. Slater, and V. M. Catanese. 1994. Induction of myocardial insulin-like growth factor-I gene expression in left ventricular hypertrophy. Circulation. 89:799-809.

45. Mann, D. L., R. L. Kent, and G. Cooper IV. 1989. Load regulation of the properties of adult feline cardiocytes: growth induction by cellular deformation. Circ. Res. 64:1079-1090.

46. Sadoshima, J., L. Jahn, T. Takahashi, T. J. Kulik, and S. Izumo. 1992. Molecular characterization of the stretch-induced adaptation of cultured cardiac cells: an in vitro model of load-induced hypertrophy. J. Biol. Chem. 267: 10551-10560.

47. Sadoshima, J., and S. Izumo. 1993. Mechanical stretch rapidly activates multiple signal transduction pathways in cardiac myocytes: potential involvement of an autocrine/paracrine mechanism. EMBO (Eur. Mol. Biol. Organ.) J. 12:1681-1692.

48. Bishop, J. E., J. J. Mitchell, P. M. Absher, L. Baldor, H. A. Geller, J. Woodcock-Mitchell, M. J. Hamblin, P. Vacek, and R. B. Low. 1993. Cyclic mechanical deformation stimulates human lung fibroblast proliferation and autocrine growth factor activity. Am. J. Respir. Cell Mol. Biol. 9:126-133.

49. Antonio, J., and W. J. Gonyea. 1993. Progressive stretch overload of skeletal muscle results in hypertrophy before hyperplasia. J. Appl. Physiol. 74: 1893-1898.

50. Wilson, E., Q. Mai, K. Sudhir, R. H. Weiss, and H. E. Ives. 1993. Me- chanical strain induces growth of vascular smooth muscle cells via autocrine action of PDGF. J. Cell Biol. 123:741-747.

51. Ivester, C. T., R. L. Kent, H. Tagawa, H. Tsutsui, T. Imamura, G. Cooper IV, and P. J. McDermott. 1993. Electrically stimulated contraction accelerates protein synthesis rates in adult feline cardiocytes. Am. J. Physiol. 265: H666-H674.

52. Kubisch, C., B. Wollnik, A. Maass, R. Meyer, H. Vetter, and L. Neyses. 1993. Immediate-early gene induction by repetitive mechanical but not electrical activity in adult rat cardiomyocytes. FEBS Lett. 335:37-40.

53. Sadoshima, J.-I., T. Takahashi, L. Jahn, and S. Izumo. 1992. Roles of mechano-sensitive ion channels, cytoskeleton, and contractile activity in stretchinduced immediate-early gene expression and hypertrophy of cardiac myocytes. Proc. Natl. Acad. Sci. USA. 89:9905-9909.

54. Morino, N., T. Mimura, K. Hamasaki, K. Tobe, K. Ueki, K. Kikuchi, K. Takehara, T. Kadowaki, Y. Yazaki, and Y. Nojima. 1995. Matrix/integrin interaction activates the mitogen-activated protein kinase, p44erk-1 and p42erk-2.J. Biol. Chem. 270:269-273.

55. Yamazaki, T., K. Tobe, E. Hoh, K. Maemura, T. Kaida, I. Komuro, H. Tamemoto, T. Kadowaki, R. Nagai, and Y. Yazaki. 1993. Mechanical loading activates mitogen-activated protein kinase and S6 peptide kinase in cultured rat cardiac myocytes. J. Biol. Chem. 266:12069-12076.

56. Parlow, M. H., D. L. Bolender, N. P. Kokan-Moore, and J. Lough. 1991. Localization of bFGF-like proteins as puctuate inclusions in the preseptation myocardium of the chicken embryo. Dev. Biol. 146:139-147.

57. Spirito, P., Y.-M. Fu, Z.-X. Zu, S. E. Epstein, and W. Casscells. 1991. Immunohistochemical localization of basic and acidic fibroblast growth factors in the developing rat heart. Circulation. 84:322-332.

58. Sugi, Y., J. Sasse, and J. Lough. 1993. Inhibition of precardiac mesoderm cell proliferation by antisense oligodeoxynucleotide complementary to fibroblast growth factor-2 (FGF-2). Dev. Biol. 157:28-37.

59. Padua, R. R., and E. Kardami. 1993. Increased basic fibroblast growth factor (bFGF) accumulation and distinct patterns of localization in isoproterenol-induced cardiomyocyte injury. Growth Factors. 8:291-306.

60. Clarke, M. S. F., R. W. Caldwell, H. Chiao, K. Miyake, and P. L. McNeil. 1995. Contraction-induced cell wounding and release of fibroblast growth factor in heart. Circ. Res. 76:927-934.

61. Yamazaki, T., I. Komuro, S. Kudoh, Y. Zou, I. Shiojima, T. Mizuno, H. Takano, Y. Hiroi, K. Ueki, K. Tobe, et al. 1995. Angiotensin II partly mediates mechanical stress-induced cardiac hypertrophy. Circ. Res. 77:258-265.

62. Fishel, R. S., V. Thourani, S. J. Eisenberg, S. Y. Shai, M. A. Corson, E. G. Nabel, K. E. Bernstein, and B. C. Berk. 1995. Fibroblast growth factor stimulates angiotensin converting enzyme expression in vascular smooth muscle cells. Possible mediator of the response to vascular injury. J. Clin. Invest. 95: 377-387.

63. Perrella, M. A., T. Maki, S. Prasad, D. Pimental, K. Singh, N. Takahashi, M. Yoshizumi, A. Alali, S. Higashiyama, R. A. Kelly, et al. 1994. Regulation of heparin-binding epidermal growth factor-like growth factor (HB-EGF) mRNA levels by hypertrophic stimuli in neonatal and adult rat cardiac myocytes. J. Biol. Chem. 269:27045-27050.

64. Backx, P. H., W.-D. Gao, M. D. Azan-Backx, and E. Marban. 1994. Mechanism of force inhibition by 2,3-butanedione monoxime in rat cardiac muscle: Roles of $\left[\mathrm{Ca}^{2+}\right]_{\mathrm{i}}$ and cross-bridge kinetics. J. Physiol. 476:487-500.

65. Miyamoto, M., K.-I. Naruo, C. Seko, S. Matsumoto, T. Kondo, and T. Kurokawa. 1993. Molecular cloning of a novel cytokine cDNA encoding the ninth member of the fibroblast growth factor family, which has a unique secretion property. Mol. Cell. Biol. 13:4251-4259.

66. Vagner, S., M.-C. Gensac, A. Maret, F. Bayard, F. Amalric, H. Prats, and A.-C. Prats. 1995. Alternative translation of human fibroblast fibroblast growth factor 2 mRNA occurs by internal entry of ribosomes. Mol. Cell. Biol. 15:35-44.

67. Wiedlocha, A., P. O. Falnes, I. H. Madshus, K. Sandvig, and S. Olsnes. 1994. Dual mode of signal transduction by externally added acidic fibroblast growth factor. Cell. 76:1039-1051.

68. Clarke, M. S. F., R. Khakee, and P. L. McNeil. 1993. Loss of cytoplasmic basic fibroblast growth factor from physiologically wounded myofibers of normal and dystrophic muscle. J. Cell Sci. 106:121-133.

69. Benzaquen, L. R., A. Nicholson-Weller, and J. A. Halperin. 1994. Terminal complement proteins C5b-9 release basic fibroblast growth factor and platelet derived growth factor from endothelial cells. J. Exp. Med. 179:985-992.

70. Steinhardt, R. A., G. Bi, and J. M. Alderton. 1994. Cell membrane resealing by a vesicular mechanism similar to neurotransmitter release. Science (Wash. DC). 263:390-393. 